\title{
Pakistan: Civil-Military Relations in a Post-Colonial State
}

\author{
Ejaz Hussain
}

\begin{abstract}
This article has attempted to explain why the military has remained a powerful political institution/force in Pakistan. Its purpose was to test a hypothesis that posited that the colonial authority structure and the 1947 partition-oriented structural dynamics provided an important structural construct in explaining politics and the military in post-colonial Pakistan.

To explain and analyse the problem, the study used books, journals, newspapers and government documents for quantitativel explanatory analysis. The analysis has focused on the military in the colonial authority structure in which the former, along with the civil bureaucracy and the landed-feudal class, formed an alliance to pursue politico-economic interests in British India. The article has also explained and analysed the partitionoriented structural dynamics in terms of territory (Kashmir) and population (Indian refugees). The findings proved that these 'structural dynamics' have affected politics and the military in Pakistan.

The theoretical framework in terms of 'praetorian oligarchy' has been applied to structurally explain colonial politics as well as politics and the military in Pakistan. The study treated Pakistan as a praetorian state which structurally inherited the pre-partition 'praetorian oligarchy'. This praetorian oligarchy constructed 'Hindu India' as the enemy to pursue politico-economic interests. The military, a part of praetorian oligarchy, emerged from this as a powerful political actor due to its coercive power. It has sought political power to pursue economic objectives independently.
\end{abstract}




\section{Background}

The partition of British India gave birth to two independent states of India and Pakistan in August 1947. Contrary to India which got established democratic institutions, Pakistan set for the opposite. The bureaucrats ruled the country with the military as an ally until the late 1950s (Alavi, 1990). In 1958, the military overtly intervened into politics and governed the country until 1971.

A civilian, Zulfiqar Ali Bhutto, served as prime minister for almost five years until the late 1970s. In July 1977 martial law was again declared in Pakistan by the military, led by General Zia. The military regime ruled the country for next eleven-and-a-half years. However, the post-Cold War period permitted civilian politicians to perform on the political platform of Pakistan. After a decade or so, the civilian leadership was once again sent home by another military coup, this time led by General Pervez Musharraf in October 1999. Since then, soldiers have run the country.

One wonders why the military is still a powerful political institution/force in Pakistan in the 21st century when most of other the former military-ruled countries, such as Turkey, have witnessed, at least, procedural democracy.

This article considers the military rule in Pakistan as an important structural development which has extremely influenced the state and society. An attempt to explain the nature of military rule would help us analyse the nature of politics, state, and the civil society in Pakistan.

Even contemporaneously, the US-led war on terrorism, the unresolved issues between nuclear India and Pakistan, and Washington's geo-strategic concerns in South Asia in terms of China's containment, a military role of Pakistan is demanded by such geostrategic developments. Thus, a Pakistan governed by soldiers offers little for the admirer of parliamentary democracy and peace. In this complex national and regional geopolitical scenario, it becomes necessary to explain politics and the military in Pakistan. 


\section{Aim of the research}

This article is about the military and politics in Pakistan. The research problem posed in this study is to explain why the military is still a powerful political institution/force in Pakistan. The purpose of the study is to test a hypothesis that the colonial authority structure and the experience of Partition (1947) have oriented structural dynamics in providing an important structural construct which explains politics and the military in post-colonial Pakistan.

In this respect, the study will deal with following questions:

- Whether the military played any political role under the British;

- Whether there were factors which helped the military become politically a powerful institution in Pakistan;

- The way the military achieved its powerful political status

As will be explained, the country has witnessed a power game among various political and non-political forces - i.e., the civilmilitary bureaucracy and political community. It is, however, the structure of the state which determines the power dynamics in the country. Therefore, I tend to explain the research problem from a historical-structural perspective.

\section{Literature review}

There is an abundance of literature on military, civil-military relations, and general politics in Pakistan. I have used the following typology in order to categorise different literature:

- Propagandists: those who look at the military as an instrument of nation building and a modernising force.

- Conspiracy theorists: those who view the military as conspiring with foreign powers, especially the US, to gain and consolidate its power at the expense of political forces.

- Instrumentalists: those who see the military from the prism of external forces.

- Elite bargain theorists: who tend to view political developments from the elite perspective. 
116 - Structuralists: those who explain the military in a larger context of the Pakistani state.

This is informed by the work of Siddiqa (2007), who used this typology. However, I have included my own sources, language, and analysis to the present typology. Moreover, I have included elite bargain theorists, below.

To begin with, authors such as General Fazle Muqeem Khan (1960:67-199), Huntington (1968:250-255), Burki (1991:1-16) and Pervaiz Iqbal Cheema (2002:135-158) have viewed the military as a nation builder. Being the most modern institution, the military has inserted itself into politics. Incompetent political leadership has compelled an otherwise reluctant military to govern. This propagandist literature has virtually regarded military as a neutral political umpire with a natural desire to serve as protector of the state. It simply has not explained the causes which force the military to intervene in politics.

The work of Ayesha Jalal (1991:27-135), Saeed Shafqat (1997:715, 35-57), Tariq Ali (1970:74-144) and Husain Haqqani (2005:41250) has constituted the second type which has painted the military as highly exploitative in fulfilling its institutional and organisational interests. Jalal even argued that the Pakistan army aligned with Britain and then with the US in an attempt to underscore national political forces.

Her narrative, however, was based on a linear-historical description of events that explained the inactivity of the civilian leadership. The civil bureaucracy was viewed as a rent-seeking institution, materially and politically benefiting through its alliance with Washington. The relative strength of political institutions was next to nothing as there was an underlying conspiracy to strengthen bureaucracy at the expense of social and political forces in Pakistan.

Jalal (1995:16-38) has further elaborated her previous work with no significant analytical modifications. In both of her accounts, the author has treated bureaucracy, particularly the military, as a post-independence phenomenon. Similarly, Shafqat, while viewing the military as a post-independence phenomenon, has developed 
the concept of the 'military-dominant party hegemonic system' to discuss politics from Zulfiqar Bhutto to Benazir Bhutto.

He has treated the pre-1971 period as partially hegemonic which could be considered arguable. In addition, the writer has only emphasised the political hegemony of the military, thus ignoring socio-economic dimensions of the concept.

The instrumentalist view has been comprised largely of the work by Stephen Cohen (2004: 87-130 see also 1984). In his two books on Pakistan and its army, he has shed light on the regimental and organisational aspects of Pakistan Army from the prism of the US interests. The author, however, has not touched the domestic factors in analysing the civil-military relations in the country.

The so-called elite bargain approach, as applied by Maya Chadda (2000:13-97, 226-232), has narrated the politics in Pakistan from the elitist mindset. This has been essentially marked as a supreme force capable of using even coercive measures to democratise, integrate and consolidate the state in Pakistan. One simply wonders whether the elite — civil-military bureaucracy, and politicians — 'consolidated' the country in 1971. But this approach is defective, as it creates the myth of an elitist leadership riding over a monolithic nationalism. Moreover, it reduces or better ignores the role of the masses in shaping the political developments in the country. In addition, it implicitly encourages the armed forces to apply unnecessary violence in the name of national consolidation to fulfil its own institutional and organisational interests.

The military's power has been studied as a structural problem by Hamza Alavi (1988, 1990), Hassan Askari Rizvi (2000: 51-240), Mohammad Waseem (1994: 42-59, 85-101) and Ayesha Siddiqa (forthcoming). Alavi's theoretical work, with respect to state and its dominant classes, has doubtlessly been monumental.

According to him, the state in his Marxian context was an 'overdeveloped' structure having strong capitalist links with the 'metropolitan bourgeoisie'. The 'landed-feudal' class, along with the 'indigenous bourgeoisie', were striving to collaborate with the civil bureaucracy to further their interests politically, economically, and 
socially.

The thrust of Alavian thought is that the bureaucracy is central to the state structure in Pakistan, whereby the state functions autonomously of the dominant 'classes'. In their bid for political power, when engulfed by political crisis the three classes - landedfeudal class, indigenous bourgeois, and metropolitan bourgeois resort to the bureaucracy and the charismatic military for arbitration.

Despite the significance of Alavi's work, room for improvement remains. For instance, the author has not been clear about the concept of 'overdeveloped' state. How and why has he assumed so? Would the state be considered overdeveloped vis-à-vis civil society? If yes, then the dominant landed feudal and indigenous bourgeoisie would be part of the society and they would be developed at least functionally in enhancing their politico-economic interests.

Another way to understand Alavi's thesis is by looking at state institutions. If we look at the elected institutions such as parliament, then sadly we find that they have not established themselves even after 58 years. The only developed state institution is, as we see later, the civil-military bureaucracy which, it seems, Alavi in his Marxian 'peripheral capitalism' paradigm has equated with an 'overdeveloped' state.

Similarly, Rizvi's work is mainly about the corporate interests of the officer cadre. Their personal interests are dubbed national interests. Unfortunately, this work has been more descriptive than analytical, and has taken the military as a post- independence phenomenon.

On the other hand, Waseem has very convincingly established the transformative links from the colonial civil bureaucracy to the new state of Pakistan. The civil bureaucracy was well trained and disciplined in the art of administration and politics under the British. Pakistan inherited a good share of this 'colonial legacy' which underscored the existence of political and social forces due to the structural nature of the colonial state.

Waseem, however, has paid little attention to the non-civil bureaucracy — the military — which has been part and parcel of the 
colonial state structure, as shall be explained later. Besides, the author has believed in the continuum of the rule of law since partition. I would challenge this argument by emphasising the superficiality of the rule of law.

Finally, Ayesha Siddiqa has explained for the first time the internal economy of the military. The military economically emerges as a 'class' in Pakistan due to its economic ventures. The originality of this work aside, the author, like others, has taken the military as a post-independence phenomenon. In addition, she, like Alavi, seemed to have equated the state with the military class. Besides this, the military has been explained as an instrument of the civil bureaucracy and political leadership.

\section{Theoretical framework}

Having reviewed the literature I found that none of the work has touched on the military as a pre-partition phenomenon. None has attempted to explore and explain the colonial authority structure in terms of identifying the colonial military, its politics and its economy. In addition, there has been a lack of analysis in terms of explaining the structural links of colonial military and its economy with that of Pakistan.

To explain the politics in Pakistan where the civil-military bureaucracy has played an important role in terms of influencing state institutions and the civil society, I tend to apply the concept of 'praetorian oligarchy' or praetorianism. This pertains to a society and/ or state where religious, feudal, and armed forces form an alliance to rule the roost.

Praetoriansim has theoretically been defined and developed by many authors such as Perlmutter (1974: 5), who has argued that "praetorianism has exited in all historical periods". Military intervention in politics in the democratising societies has been analysed as a common phenomenon by such authors.

The level of political culture of a given society to a large extent determines the course of its political development. In this respect, Huntington (1968: 80) has introduced the concept of 
120 'praetorian polities'. Among the praetorian polities he identified 'oligarchical praetorianism' where the influential social forces were "the great landowners, the leading clergy, and the wielders of the sword” (Huntington 1968: 199). He further argued that: “...the most important causes of military intervention in politics are not military but political and reflect not the social and organisational characteristics of the military establishment but the political and institutional structure of the society" (1968: 194).

Similarly, Amos Perlmutter (1974:4-20) has also developed the praetorian perspective in terms of military praetorianism, whereby the military played "a highly significant role in key political structures and institutions". In addition, he has identified two types of praetorian armies: the arbitrator army and the ruler army. The arbitrator military, having established its writ, preferred to return to barracks due to time limits, acceptable social order, lack of independent political organisation, and fear of civilian retribution, etc. The ruler type of military has a propensity to stay in power. In this approach, the military remained the dominant political power and was bent on maximising its power and perks.

In Modern Authoritarianism, Perlmutter (1981:1-13) has categorised praetorianism as one type of a modern authoritarian system. The types of modern authoritarianism are dominated by oligarchic political elites. The military as a 'parallel and auxiliary' institution is used as instrument by the political elite in praetorianauthoritarianism.

Thus, the thrust of the above-mentioned theoretical framework is on oligarchy/alliance of the landed feudal, armed forces, and clergy. This oligarchy theoretically becomes praetorian then when military is included. Overall, the existence of a praetorian oligarchy marks a low level of political culture in a given society, as argued by Huntington.

To explain my research problem, I have tended to apply 'praetorian oligarchy' as a theoretical framework on the colonial state and society. I have argued that the Alavian landed-feudal class and civil-military bureaucracy form a 'praetorian oligarchy' to pursue its politico-economic interest in British India. 
Similarly, I have applied the same framework on the postcolonial state of Pakistan where the state, to be explained later, has inherited the 'praetorian oligarchy' consisting of landed-feudal class and the civil-military bureaucracy.

I have, however, excluded clergy from this Huntingtonian 'oligarchical praetorianism'. Instead, I have argued that clergy was auxiliary/supportive to the landed feudals and the civil-military bureaucracy. Besides, unlike Perlmutter and Siddiqa, I have not taken the military as auxiliary or as an instrument of the civil bureaucracy and the landed-feudal class.

Rather, I have argued that the military was a colonial phenomenon and, structurally, was a part of colonial praetorian oligarchy which existed in British India as we shall see. In post-partition Pakistan the military intervened in politics due to its structural understanding with the pre-partition praetorian oligarchy to perpetualise its politicoeconomic interests.

I have also argued that the military in Pakistan's politics did not function independently but, rather, was part of the praetorian oligarchy. However, within this praetorian oligarchy it has become Perlmuter's 'ruler' military.

Besides, adhering to the new version of structuralism, I have used the state as 'autonomous' from dominant classes. In addition, I have tended to emphasise the centrality of the state. The dominant classes and even institutions - civil-military bureaucracy — function within the state and not as the state (Steans and Pettiford 2005: 55$58,86-88)$.

\section{Methodology}

The existing material on military and politics in Pakistan is mostly descriptive, theoretically ambiguous, and highly pro-military. More importantly, it does not take the military's politics as a prepartition phenomenon as mentioned earlier. Therefore, there are many missing links needing to be explained.

Thus, in order to explain the research problem I have tended to test a hypothesis which was also the purpose of this study. The 
122 hypothesis is that the colonial authority structure and partitionorientated structural dynamics provide an important structural construct in explaining politics and the military in Pakistan. This hypothesis is expected to help us explain the military and politics in the post-colonial state of Pakistan.

In order to test the hypothesis, I came across a book published in 2005 by Tan Tai Yong. The book was a first of its kind and was originally a doctoral dissertation. It convincingly discusses the colonial military and its politics in the Punjab from 1849 to 1947. I have relied on this book in terms of quantitative/qualitative facts to explain the military's role in the colonial authority structure. However, this was a secondary source. In addition, I have referred to another book (originally a doctoral dissertation) to explain the role of civil bureaucracy in the British authority structure. The book also covered general politics of colonial India.

To explain the phenomenon of the 1947 partition, I was able to go through another original work published for the first time in 2005 in the form of a book. This secondary source has helped me a lot in terms of explaining the partition from colonial perspective. This work refuted the earlier theories with respect to London's plans to divide India. In addition, I accessed some primary material in terms of the Pakistan Census Report (1951) to quantitatively explain the impact of Indian refugees (mohajirs) on Pakistani politics.

I had planned to conduct interviews with military personnel in order to gain insights into the military's politics and economic ventures to explain my research problem. Unfortunately, the accessibility to the concerned persons was made difficult due to their strategic engagement - i.e. war on terror.

To solve this problem, I gained accessed to one Pakistani security analyst with expertise on the country's military and its economic activities. I have used this source quantitatively to explain military's' economic role. The source, however, was treated as secondary. Besides, I have cited another primary source - the Parliamentary Directory (a government document) — to explain the socio-cultural background of Pakistan's current parliament. 
Also, I have used another primary source in the Pakistan

Planning Commission's Report on poverty incidence during the last four years. This source has been used quantitatively. Thus, I have used secondary sources — i.e., books, journals, and newspapers - at times quantitatively to explain and analyse politics and the military in Pakistan. In addition, primary sources, such as reports, have been mostly used for quantitative analysis. I have relied on quantitative facts in the data collected because it would help to test my hypothesis, answer the questions, and analyse the problem with the help of theoretical framework.

Finally, I am aware that I have mainly focused on Pakistan's military and general politics. Also, I have excluded a very useful narration of political developments, such as a detailed description of Pakistan's partition in 1971 or nuclear tests in 1998, due to space constraints. Since the ambition was to explain the problem which has not been dealt with, unnecessary details have been avoided so to fully concentrate on the problem instead.

\section{Disposition}

I have divided this article into three parts. The first part explains and analyses the colonial authority structure. It argues that the praetorian oligarchy existed in British India. The 1947 partition is also explained from a colonial perspective. In addition, this chapter highlights partition-oriented structural dynamics.

The second part deals with politics in post-partition Pakistan. An attempt is made to explain whether the colonial authority structure and the partition-oriented structural dynamics have any bearing on politics and the military in the post-colonial state of Pakistan. Besides, this part argues that the pre-partition praetorian oligarchy was structurally inherited by the Pakistani state. The military being a component of this oligarchy emerges powerful politico-economically due to the structure of the state and society.

The last part explains the partition and disintegration of Pakistan in 1971. The new state inherited the Punjab-based 'praetorian oligarchy' from the old state of Pakistan. This part generally explains 
124 politics and the military's politico-economic activities from partition until present. The findings of the three parts are surmised in the conclusion.

\section{Colonial politics}

This part explains the colonial authority structure. It explains how the civil-military bureaucracy and the landed-feudal class formed a praetorian oligarchy/alliance to pursue their politico-economic interests in British India. The chapter also explains the partition of British India in 1947. The partition-oriented structural dynamics are also highlighted in this chapter.

\section{Colonial authority structure}

The authority structure of the British Empire comprised the governor-general, the viceroy and the state bureaucracy. This power system was answerable via the sectary of state to the British parliament in London. The state bureaucracy was an integral part of this authority structure.

The state acted as an interventionist force to pursue its capitalist interests. In this respect, it was the bureaucracy which enjoyed an arbitrary position in terms of bureaucratic paternalism. The role of the landed feudal was effectively reduced by the state-led economic mechanism, affected and regulated in turn by the market. The state penetrated and influenced civil society through the bureaucracy (Waseem 1994: 27-28).

The forces of colonialism gradually replaced the Moghul state (empire) structure. Bengal and the Punjab succumbed to the British East India Company in the mid-18th and mid-19th centuries respectively. The British developed an operative 'institutional' setup for the administration of the colonial society. The political economy of colonialism made the state act as promoter, guarantor, and protector of British capitalist interests in India. On the other hand, the state functioned as an organisation 'relatively autonomous' of these interests as well as from local politico-economic forces (Waseem 1994: 21-27). 
Waseem, however, has not differentiated between the types of colonial state bureaucracy. His sole emphasis on the civil bureaucracy has not given a complete picture of the colonial authority structure. Tan Tai Yong, has, however, convincingly established the linkage between the landed-feudal class and the British military, forming the praetorian oligarchy in pursuit of politico-economic interests.

Yong has emphasised the 'culture of militarism' of the precolonial Punjab. India throughout its history witnessed invasions from its northern parts called the Punjab. In the wake of the Moghul decline, the Punjab was conquered and governed by Maharaja Ranjit Singh. He raised his own army mainly comprising Punjabi Sikhs. The East India Company regime annexed the Punjab in 1849. The next decade saw demilitarisation of the defeated Ranjit's army. The 1857 mutiny, however, made the British re-evaluate the strategic importance of the Punjab as well as the Punjabis who had earlier supported the 'military-fiscal state' of the company's rule (Yong 2005: 19-51).

In the 1880s soon after the Second Afghan War, the colonial masters perceived the so-called 'great game' that was the Russian threat. The 'martial races' concept was developed by the British authorities to 'divide and rule' not only the armed forces but also India. The 'Punjabicisation' of the colonial military initiated the recruitment of Punjabi Sikhs, Punjabi Muslims and Pathans of north India — the military districts — into the restructured Bengal Army (Yong 2005: 57-89).

In the 1890 s the opening of 'canal colonies' initiated a process of land allocation by the colonial masters to win the loyalty of the soldiering classes. In 1900 the Land Alienation Act was passed by the state to stop land slipping out of hands of the landed-feudal class. Coincidentally, this landed-feudal class consisted of ex-soldiers, pensioners, and relatives of in-service army personnel. From 19141919, the Punjab provided a majority of recruits to safeguard the colonial interests in Asia, Africa, and Europe (Yong 2005: 90-108).

The war years brought close collaboration between the civil and military authorities, giving birth to the concept of 'militarised 
126 bureaucracy'. The chaotic economic situation after the war years, along with the political uprisings of, for example, the Khilafat movement, threatened the socio-economic balance in the rural-military districts. As a result, civil-military cooperation in terms of Punjab Soldiers' Boards was further consolidated (Yong 2005: 141-182).

This civil-military integration was a planned mechanism to prevent the recruiting districts being influenced by nationalist politics of the post-war period. In other words, the British authorities were instrumental in the creation of praetorian oligarchy. Thus, during the inter-war period (1919-1939), the Punjab Soldiers Board functioned as an institutional part of the district administration (see Alavi 1988).

However, the nationalist movement gained momentum during the inter-war period. The raj was political, too. In revising the 1909 Morley-Mitno reforms, it blessed the Indians with limited representation by introducing Montagu-Chelmsford reforms in 1919. However, in post-reformist India, both the Congress and the League failed to make political in-roads into the praetorian Punjab which provided 60 percent of the Indian army by 1927. Instead, the Punjab-based Unionist Party, an alliance of Hindu, Muslim, and Sikh landed feudal, held on to power until the last days of the raj. The Unionist Party clearly represented the praetorian oligarchy, especially in the military districts of northern Punjab (Yong 2005: 241-280).

Thus, it is argued that the colonial authority structure comprised both the civil and military bureaucracy, along with the governorgeneral and viceroy. The British recruited Punjabis in large numbers from late 19th century onward to the British Indian Army to secure the imperial boundaries from the Russian threat. The British won the loyalty of the military districts in northern Punjab through a systemic allocation of land. In the inter-war period, the civil-military bureaucracy and landed feudal collaborated with one another politically and economically. Their collaboration gave birth to a praetorian oligarchy in British India.

\section{The strategic partition}

There are numerous theories with respect to the partition of British India. Hamza Alavi $(1988,1990)$ has advanced the 'salariat 
theory', arguing that the salaried classes, such as lawyers of United and Central provinces, as well as Bengal and the Punjab, strove constitutionally to safeguard their economic interests. However, Khalid bin Sayeed has emphasised Muslim separatism. His thesis was based on civilisational differences between the Muslims and the nonMuslims of India. Sayeed, undoubtedly, represented the two-nation theorists (Sayeed 1967:4).

Waseem, on the other hand, has based his findings on multiplicity of variables. Structurally, the Pakistan Movement started in the Muslim-minority provinces. Ideologically, it was the twonation theory that served as an ideology. Organisationally, it was the Muslim League which provided the platform to the Indian Muslims. Personally, it was Jinnah's Weberian charisma that was the driving force. Nonetheless, Waseem, if studied deeply, also belongs to the two-nation strand (Waseem 1994:59-83).

Similarly, Jalal (1991:16) also laid emphasis on the personality factor. She, however, differed from others in the sense that Jinnah was not necessarily struggling to win independence. His acceptance of the Cabinet Mission Plan in 1946 marked his political resilience. Jinnah used the demand for Pakistan as a bargaining chip to maximise the Muslims' interests, argued Jalal.

The academic value of the above-mentioned theories appreciated, I instead tend to explain the partition phenomenon from the colonial perspective. After all, it was the British, not the Congress or the Muslim League, which partitioned the sub-continent.

In this respect, in his recently published work In the Shadow of the Great Game, Narendra Singh Sarila has convincingly unfolded the story of India's partition. His thesis was based on declassified archival facts about the way the British made policies to preserve its geostrategic concerns during the Second World War.

The Congress, due to its own nationalist politics, resigned from the office in eight out of 11 provinces in 1939 just after the war broke out in Europe. On the other hand, the British wanted to have a strife-free Punjab (where it recruited 50 percent of the British Indian Army). In this respect, the Muslim League and its 
128 leadership especially Jinnah was appeased by Lord Linlithgow, who in announcing the British declaration on 8 August 1940, acceded the 'veto' to Jinnah on India's future constitutional developments. Even the Unionist leadership, which was part of the praetorian oligarchy, was urged by Lord Linlinthgow to enter into electoral alliance with the League. Jinnah, who thought on communal lines much earlier in 1939, conversed with Lord Linlinghtgow that the "Muslim areas should be separated from 'Hindu India' and run by Muslims in collaboration with Great Britain” (Sarila 2005: 34-64).

In the wake of poor British performance in the war, the division in the Imperial army, the Congress's demand for a free-India and the League's 'autonomous' rhetoric, it was Lord Wavell, not Mountbatten, who first blueprinted the future of Pakistan on 6/7 February 1946. Responding to a telegram to the secretary of state for India, Wavell, while forwarding his scheme, gave great importance to the communists' interventionist designs towards the Middle East (the wells of power), and rest of Asia (Sarila 2005: 194-196).

To contain and combat this menace, the support of the Muslims was crucial. In this respect, an independent Pakistan was perceived to serve as a military base in fulfilling the British strategic aims. Hence, British India was partitioned into India and Pakistan. Bengal and the Punjab were also partitioned into East Bengal (in Pakistan) and East Punjab (in India) in August 1947. The princely states, including Kashmir, were denied independence by London. Soon after the transfer of authority to India and Pakistan on August 15, 1947, the two countries started integrating the princely states under the partition formula (Sarila 2005:330-336).

Therefore, it is in this context of partition that the issue of Kashmir's integration and the cross-border migration needs explanation. Moreover, I have termed such developments as 'partitionoriented structural dynamics' because they were part of the colonial state in terms of territory and population. I would explain later how these 'structural dynamics' affected the military and politics in postpartition Pakistan.

Thus, it has been argued that the British authority structure was 
decisive in terms of policy making and implementation. Moreover, the Punjab proved crucial as a recruiting ground for the Imperial army. The soldiering classes were granted land in order to win their loyalty and depoliticise them. The British strategically partitioned India on communal lines in August 1947. Moreover, the partition left a legacy of 'structural dynamics' that have affected the state of Pakistan as we see in the next chapter.

\section{Praetorian Pakistan}

This part argues that Pakistan is a praetorian state which inherited the pre-partition praetorian oligarchy. Also, it explains if the colonial authority structure and the partition oriented structural dynamics affect politics and the military in Pakistan.

\section{Punjab-based praetorian oligarchy}

Territorially, Pakistan inherited North West Frontier Province, West Punjab (onward Punjab), East Bengal, Sind, and a few princely states including Bahawalpur, whose rulers under the partition formula acceded to Pakistan. The British Balochistan, comprising princely states of Kharan, Lasbela, and Kalat, was raided by the Pakistan army in March 1948, annexing it with the latter (Tariq Ali 1983:123; Jalal 1991:93). In addition, the country had to struggle to get its material — i.e. bank balance, and arsenal — and non-material — i.e. military personnel, and bureaucrats — shares (Rizvi 2000: 35-61; Haqqani 2005: 11-12).

Besides, Pakistan received in total more than seven million Indian refugees (mohajirs) of which more than five million settled in Punjab alone - two percent of which came from United provinces and mostly settled in urban Sind, i.e. Karachi (Census of Pakistan 1951: 11-25). The Muslim League and its leadership, including Jinnah, were migratory as well. Punjab and Bengal emerged as the two largest provinces in area and population.

Scholars and analysts have so far focused on those mohajirs who spoke Urdu and settled in urban Sind (Waseem 1994: 102-111). I instead argue that the politics of Punjabi mohajirs in particular and 
130 (local) Punjabis in general is crucial to explaining their influence on politics and the military in Pakistan.

The colonial authority structure, in terms of civil-military bureaucracy, was structurally transformed into the Pakistani state. As mentioned earlier, up until partition the Punjabis had made up 50 percent of the British Indian Army. Therefore, Punjabis, both local and mohajirs, outnumbered even majority Bengalis in the armed forces of Pakistan. Similarly, Pakistan inherited a good share of colonial civil bureaucracy. The local-mohajir Punjabis outgrew all other ethnic groups in the Pakistan's civil services (Waseem 1994:108). Besides, the landed feudal class of Punjab was institutionally well organised to assert itself politically (Alavi 1990). So, this overwhelming position of Punjabis was one of the dynamics of partition which affected the structure of state and military in Pakistan.

Thus, it is argued that the over-representation of Punjabis in the civil-military bureaucracy, along with the Punjabi landed feudal class, confirms the structural significance of pre-partition praetorian oligarchy which institutionally remained unaffected by the partition. Pakistan inherited this praetorian oligarchy, it is argued. In addition, I have termed this 'Punjabicisation' as a 'Punjab-based praetorian oligarchy' which exploited the country politically and economically.

\section{Overdeveloped civil-military bureaucracy}

The Punjabis outnumbered all other ethnic communities in the civil-military bureaucracy, as explained earlier. The civil-military bureaucracy consolidated its numerical strength in the absence of indigenous leadership and any political organisation. In other words, the migratory political leadership proved ineffective in putting the civil-military bureaucracy under permanent civilian control.

In post-partition Pakistan, Jinnah, the governor-general, was all powerful under the amended 1935 India Act (Alavi 1990). However, Jinnah and the Muslim League had little to say in areas now constituting the state of Pakistan. The praetorian oligarchy remained unaffected by the partition process. It provided little space to the ailing Jinnah and disenchanted Liaquat Ali Khan, the country's first prime minister (Alavi 1990). 
Instead, owing to the peculiar nature of the state which inherited an 'overdeveloped civil-military bureaucracy' and an illrepresentative Muslim League, the civil bureaucracy emerged from within the praetorian oligarchy as a powerful political actor due to its expertise in the art of administration. In the name of the governorgeneral, the Punjabi bureaucrats established a hitherto unknown post of 'secretary general' and a 'planning committee' directly responsible to Jinnah who by that time was bed-ridden. Choduary Mohammad Ali, the secretary general and later prime minister of Pakistan, bypassed Liaquat Ali Khan and his cabinet in terms of policy making and its implementation (see Alavi 1990).

It was this Punjab-based praetorian oligarchy which feared the majority Bengalis who demanded a constitution and general election. To do injustice to the Bengalis, it was Jinnah himself who declared Urdu a national language in East Bengal in March 1948. It was not to suggest that Jinnah represented this oligarchy.

It has, however, been argued that the civil bureaucracy was the real power holder and a think-tank responsible for policy input for the administrative state of Pakistan. Thus, the praetorian oligarchy had no objection to Urdu in the name of so-called nation building (Rahman 1998: 200-209).

On the other hand, the military as part of the praetorian oligarchy did not lag behind in terms of power projection. I have explained it by again looking at partition. As mentioned before, the 'strategic partition' was done in order to use Pakistan as a military base. Therefore, the British had opted for a joint defense council for India and Pakistan. Claude Auchinleck was joint commanderin-chief of Indian and Pakistani armed forces. All three services of Pakistan were headed by British officers in the initial years (Rizvi 2000: 41).

Jalal (1991: 118), in this respect, has argued that the British deliberately did so as they wanted to make Pakistan dependent on London for its defense needs. Her argument was in line with Sarila, as we have seen before. However, this type of argumentation underscores the value and the purpose of partition. Instead, it has 
132 been argued that the British did want to see Pakistan as an ally in its global power calculations - in particular, as an anti-communist force. The assumption of the officer cadre of Pakistan's armed forces by the British was primarily due to the ineffective political leadership of Pakistan which had failed badly to take defense into its own hands.

Table 1 Defense expenditure: 1949-1958

\begin{tabular}{|c|c|c|}
\hline Year & $\begin{array}{c}\text { Defense expenditure } \\
\text { (Rs. million) }\end{array}$ & $\begin{array}{c}\text { Percentage of the } \\
\text { total government } \\
\text { expenditure }\end{array}$ \\
\hline $1947-48^{*}$ & 236.0 & 65.16 \\
$1948-49$ & 461.5 & 71.32 \\
$1949-50$ & 625.4 & 73.06 \\
\hline $1950-51$ & 649.9 & 51.32 \\
\hline $1951-52$ & 792.4 & 54.96 \\
\hline $1952-53$ & 725.7 & 56.68 \\
\hline $1953-54$ & 633.2 & 58.7 \\
\hline $1954-55$ & 640.5 & 57.5 \\
\hline $1955-56$ & 917.7 & 64.0 \\
\hline $1956-57$ & 800.9 & 60.1 \\
\hline $1957-58$ & 854.2 & 56.1 \\
\hline $1958-59^{* *}$ & 996.6 & 50.9 \\
\hline
\end{tabular}

* 15 August 1947 to 31 March 1948, ** 1 April 1958 to 30 June 1959 Source: Rizvi 2000

The most significant development was the establishment in 1953 of Fauji Foundation (Soldier Foundation), which ventured into textile, sugar, and cereals in the name of meeting army personnel's welfare (Siddiqa 2003). Also, military personnel largely benefited due to its political position in the praetorian oligarchy with respect to the redistribution of evacuee land -land left behind by non-Muslims who migrated to India in 1947. This land was leased for 99 years to the military for operational purposes which appropriated it for personal gains (Siddiqa 2007).

This aspect of the military's economic activism makes one remember the pre-partition land allocation to the military classes by the British. Thus, in independent Pakistan, the military as an 
important component of the praetorian oligarchy strove on its own to secure its economic interest in the security state of Pakistan.

\section{Political military}

On 8 October 1958, President Iskander Mirza declared martial law in the country. The 1956 constitution and the national-provincial assemblies were abrogated and dismissed respectively (Rizvi 2000: 86). This episode has been analysed by many scholars.

Alavi has viewed it as a '(civil) bureaucratic coup' because it was Iskandar Mirza, a bureaucrat, who declared martial law. In addition, the new set-up included a secretary general and his planning committee which gave more power to the civil bureaucracy than military. Alavi and Jalal, among others, have argue that the fear of a general election that was supposed to be held in 1959 was the main reason behind martial law (Alavi 1990; Jalal 1995: 54).

Alavi, unfortunately, has focused at the means and not the end. How strange it would seem that a 'bureaucratic coup' resulted in a military intervention that sent Iskandar Mirza into exile. In addition, why did the election - which had been postponed many times since 1947 — become the cause for the coup?

It has been argued that it was a 'military coup' initiated by the military, bringing all power into its hands. The main cause was not the election but the projection of the military as 'ruler' in the Punjabbased praetorian oligarchy. The military achieved this seniority due to its overwhelming politico-economic position in the security state of Pakistan. In addition, it sought political power to expand and consolidate itself as an independent economic actor. This shall be explained later.

Besides, the abrogation of the constitution may be seen in the light of 'necessity doctrine'. It meant, it has been argued, that the legal and constitutional norms were irrelevant to the state of Pakistan and the so-called constitution was superficial in nature and character. The superficiality of legal-constitutional norms also showed the weakness of parliamentary institutions and civil society in Pakistan.

From 1958-69 the country was arbitrarily ruled by soldier- 
134 president general Ayub Khan, who got himself elected president through arbitrary referendum. He introduced the system of 'Basic Democracies', supposedly to democratise the country. The Muslim League was factionalised. Resultantly, the Muslim League Convention was the king's party.

Ayub also blessed the nation with a constitution in 1962. A war with India in September 1965 was, too, planned via Kashmir to humiliate the chronic foe. A year before, the soldier-president got reelected as president through the self-created Electoral College - the basic democrats (Hashami 2005: 147; Tariq Ali 1970: 132; Haqqani 2005: 43-50; see also Ziring 1971: 12-85).

The Ayub-led military rule further benefited the praetorian oligarchy. For instance, his economic polices were carried out by the civil bureaucracy which was a medium to penetrate the state and into civil society. The regime's cronies - be they of the landed-feudal class or bureaucrats - were favoured in terms of 'superficial' land reform and industrial licenses (Ziring 1971: 88). In addition, the regime amended Colonisation of Land Act, 1912, in 1965 to allot land (about 100,000 acres annually) to the military (Siddiqa 2007). Besides, the Fauji Foundation gathered assets worth Rs152 million by the end of his rule (Siddiqa 2003).

Ayub's era was anti urban and rural poor. His policies were discriminatory and the more depressed and discriminated were the majority Bengalis - politically, economically, and culturally. This mega-discrimination led to the six-point politics of the Awami League and its leader Mujibur Rehman in the mid 1960s. Poor communities of West Pakistan were also discriminated to such an extent that they took to the streets in late 1960s (Ziring 1971: 174-191; Tariq Ali 1970: 23). The public uprising against Ayub mark the flaws in the work of propagandists, such as Huntington (1968: 250-255), who echoed military-led modernisation.

A newly created Pakistan People’s Party led by Zulfiqar Ali Bhutto was instrumental in articulating the concerns of poor communities. Awami League did the same in the Eastern Wing. A defamed Ayub Khan proved a liability for the military which removed him from office 
in March 1969 (Tariq Ali 1970: 210). The deposed soldier abrogated

his own constitution and dismissed pro-regime assemblies. Martial Law once again engulfed Pakistan in March 1969. Constitutional norms once again proved irrelevant and 'superficial'.

Thus, it has been argued that the civil bureaucracy-led praetorian oligarchy ruled the country from independence until 1958. The 1958 military coup registered the military as a senior partner within the praetorian oligarchy. The military regime of Ayub Khan further consolidated the military both politically and economically. Legal and constitutional norms remained superficial and irrelevant. The urban-rural poor were extremely discriminated in both wings. This led to heightened agitation in politics, which was capitalised on by the People's Party and Awami League. Resultantly, Ayub Khan unleashed further martial law.

\section{Birth of a new state}

This part of the article explains the partition and resultant disintegration of the state of Pakistan in 1971. This chapter also explains the new state, its politics, and the military. Finally, the chapter attempts to explain how the military consolidated its politicoeconomic position within the praetorian oligarchy from 1971 until present.

\section{Partition of Pakistan}

General Yahya Khan assumed office of the chief martial law administration in March 1969. The military regime under Yahya was seen as continuation of the earlier military rule. I, however, would put the Yahya-led military rule in the praetorian oligarchy which remained undisturbed in the post-Ayub period.

Having assessed the public mood, Yahya, under his Legal Framework Order, undid the One-Unit ${ }^{1}$ and promised a general election in the country in February-March 1970. The People's Party, Awami League, and other smaller parties started canvassing without pronounced agendas. Zulfiqar Ali Bhutto played upon the poor community's emotionality in terms of promising them roti, kapra 
136 and makan (bread, cloth and a house). Mujibur Rehman sold the 'autonomy' maxim. The smaller parties, including Jamaat-e-Islami, aspired for pan-Islamism. And the Muslim League was lost with the fall of Ayub Khan (Waseem 1994: 243-254).

The election was staged with at least some reports of rigging. Though the military intelligence agencies predicted a mix-mandate, the People's Party and Awami League made a clean sweep in West Pakistan and East Pakistan respectively. From a simple parliamentary democracy principle, the majority party was entitled to form government in the centre as well as East Pakistan.

But the Punjab-based praetorian oligarchy could not accept the Bengalis ruling them. Therefore, Yahya Khan and Zulfiqar Ali Bhutto (a Sindi-landed feudal), in representing the oligarchy, dismissed the public verdict. When the Bengalis resorted to agitational politics, Yahya Khan allowed military means to solve a political issue. In the wake of the civil war, the Bengali refugees proved a burden to India socially and economically. No wonder then that India exploited the situation through war against Pakistan. As a result, on 16 December 1971, Pakistan was partitioned through the formation of the sovereign state of Bangladesh (Waseem 1994: 255-277).

Scholars so far have bypassed this partition and its ramifications. However, it has been argued that this partition marked the importance of non-religious identities. The creation of Bangladesh showed the victory of the two-culture theory whereby the dual-nation theory was not able to bind the two wings together. In addition, the partition of Pakistan confirmed the significance of 'structural supremacy' of the Punjab-based praetorian oligarchy which, for its own political and economic interests, underestimated and degraded the majority Bengalis.

More importantly, the state of Pakistan virtually disintegrated. It was run by a non-elected apparatus at the time of partition, meaning that the legality and rule of law was absent. Moreover, it lost more than half of its population and territory in a sign of the state's physical collapse.

Thus, the partition of old Pakistan gave birth to a new state 
which inherited the overdeveloped civil-military bureaucracy and influential landed-feudal class. In other words, the new state structurally inherited the Punjab-based praetorian oligarchy from the old Pakistan. In addition, Punjab once again emerged as a powerful province in terms of population and resources.

\section{Politics of appeasement}

The post-1971 Pakistani state structurally forced the military to retreat because the latter had been discredited by the masses due to its failure to guarantee even the territorial defense of the state. Therefore, the military handed over power to Zulfiqar Ali Bhutto with whom the civil-military bureaucracy had developed institutional understanding during the former's association with the Ayub-Yahya regimes. For instance, Bhutto was sent to China by the Yahya regime at a time when the military operation in East Pakistan was at its peak.

In addition, he retrospectively represented the old West Pakistan. Therefore, he was the only leader of national standing who could be transferred authority. Therefore, Bhutto acted as the country's first civilian chief martial law administrator as well as its president from late 1971 to 1973 .

Bhutto and his politics (1971-77) have been discussed by many scholars. For instance, Burki (1980: 81-89), K.B. Sayeed (1980: 91) and Jalal (1995:77-84) have analysed 'Bhuttoism' from a personalistic perspective, in that he was a feudal and once in power he wanted to maximise it at all costs. Shafqat (1997: 115-159) and Waseem (1994: 285-348) have, however, analysed the Bhutto phenomenon from a party politics perspective. These scholars have argued that Bhutto came to power due to the vote. To fulfil campaign promises, he turned to the politics of reformism. It was in the structure of reforms that resent grew among some groups or classes, and they brought him down.

The 'politics of reformism' thesis of Shafqat and Waseem was partially true. Shafqat (1997:10-16), while formulating his 'dominant party political system' for the 1971-77 period, has ignored the organisational weakness of the People's Party. Thus, it has been argued that the period of the People's Party was not what Shafqat 
138 formulated.

Waseem has, however, highlighted the organisational weakness of the People's Party which caused Bhutto's downfall. However, he has not touched the military's politics which appeased Bhutto by returning to barracks in the wake of 1971 defeat. Therefore, I would tend to argue that it was the politics of appeasement - political and economic concessions - both on the part of Bhutto and the military during this period.

Bhutto was transferred power by the discredited military. In other words, he was appeased by an organisation which was a senior partner of the praetorian oligarchy which also represented the landed feudal. Bhutto, being of the landed feudal, sought about becoming authoritarian. Through that, he was to curtail the powers of a military which had previously ruled the country. Therefore, he restructured the military command and control structure. In addition, he abolished the civil service of Pakistan and unified all services though with military's consent (Haqqani 2005:95; Shafqat 1977:167). Besides, he appeased the socialists within his party by giving them important portfolios, such as the finance ministry (Burki 1980: 140-143).

However, very soon he deployed the military in Balochistan in the name of national consolidation (Cohen 2004: 220). The Balochistan operation continued from 1973 until Bhutto's downfall (Waseem 1994: 323-327). The intelligences agencies of the military, however, exploited the situation in the former's favour (Haqqani 2005: 172). The underlying assumption was to rejuvenate the morale of the armed forces so as to regain its previous political position.

Bhutto, in his rhetoric of appeasement, projected India as the enemy when the latter tested a nuclear device in 1974 . The dynamics of the security state urged Bhutto to initiate the country's first nuclear programme in the mid 1970s. In addition, during 197277 the defense budget stood at about six percent of GNP (Shafqat 1997:167). Thus, Bhutto appeased the military to prolong his stay in power.

By the mid 1970s, Bhutto had restructured his cabinet and replaced staunch socialists with members of the landed feudal, the 
majority of whom came from Punjab. The entry of the landed-

feudal class into the corridors of power marked their importance in the praetorian oligarchy. In addition, he also appeased the religious forces by introducing Islamic measures, such as the banning of alcohol (Burki 1980: 193). The religious forces, however, along with the discriminated urban-rural poor, took to agitational politics and demanded an Islamic system. The Inter Services Intelligence (ISI) assisted and aided the religious forces in this respect (Haqqani 2005:105-116). Thus, it has been argued that the clergy was an auxiliary to the military.

Bhutto, having sensed the situation, decided to hold general election in March 1977. His People's Party emerged as a majority party. However, opposition in the form of the Pakistan National Alliance (PNA), refused to accept the results. They alleged Bhutto of massive rigging (Rizvi 2000: 232-235). Thus, the agitational politics of the PNA requested the military to take over.

\section{The military matters}

The new state witnessed martial law imposed by general Ziaul Haq military regime on 5 July, 1977, on charges of corruption and mismanagement of the economy by Bhutto. The latter was arrested and his polices reversed; the 1973 constitution was abrogated. Two years later, Bhutto was hanged by the military (Rizvi 2000:239).

Politically, Zia, like Ayub, held a referendum and became a soldier-president. The other partners in the praetorian oligarchy, especially those affected by Bhutto's policies, applauded the military rule. The Afghan jihad of the 1980s against communist Soviet Union made Islamabad a frontline state in Washington. Subsequently, massive military aid (US\$ 3.2 billion) and increased defense allocation strengthened the military at home. It became belligerent: it banned political parties, arrested anti-regime politicians and journalists, delayed oft-promised election, criminalised the civil society through a weapons-drug culture, Islamised the legal system and spilled ethnic-sectarian violence throughout Pakistan (Waseem 1994: 367-388; Burki 1991: 16). 


\begin{tabular}{|cc|}
\hline \multicolumn{2}{|c|}{ Land Entitlement for Military Personnel } \\
Rank & Acreage \\
Major General and above & 240 acres \\
Brigadiers and Colonels & 150 acres \\
Lt. Colonels & 124 acres \\
Lieutenants to Majors & 100 acres \\
JCOs & 64 acres \\
NCOs & 32 acres \\
\hline
\end{tabular}

Source: Ayesha Siddiqa (2007)

Likewise, the military operation against the nationalist Baloch in Balochistan could be explained in this context. The militaryled government started Development Projects in Gwadar which favoured Punjabis, including military (70 percent Punjabis). The Baloch resented the militarily and the conflict has continued (The Friday Times 29 October, 2004).

Thus, it has been argued that the apparent goal of the October coup — and also that of November (2007) — was to re-insitutionalise military rule and make politicians and civil society know that the military remained a powerful political force in Pakistan. However, the underlying objective of the coup was to gain political power to pursue economic interests authoritatively.

\section{Conclusion}

This article has attempted to explain why the military has remained a powerful political institution/force in Pakistan from a historical-structural perspective. In this respect, I have explored the hypothesis with respect to the colonial authority structure and partition-oriented structural dynamics. My analysis included the military in the colonial authority structure. The colonial military, along with the civil bureaucracy and the landed-feudal class, formed a praetorian oligarchy which has pursued its own political and economical interests in British India. In addition, I have analysed that the partition-oriented structural dynamics in terms of territory 
(Kashmir) and population (Indian refugees) have affected politics and the military in Pakistan. Thus, it has been argued that the hypothesis holds and I have theoretically operationalised the hypothesis in terms of pre-partition 'praetorian oligarchy' to explain my research problem.

The post-colonial state of Pakistan inherited the pre-partition praetorian oligarchy based on Punjab. The civil-military bureaucracy has structurally emerged as an 'overdeveloped' institution which has an alliance with the landed-feudal class and has projected and institutionalised 'Hindu India' to pursue political and economic interests (see the Table 4).

\section{Table 4 Evolution and consolidation of praetorian oligarchy in Pakistan}

14 Aug. $1947-18$ Oct. 1951

19 Oct.1951- 7 Oct. 1958

7 Oct. 1958- 20 Dec. 1971

20 Dec. 1971- 5 July 1977

5 July 1977-present
Politicians, oligarchically, ran the affairs of the state.

Civil bureaucracy dominated the political structure, in alliance with a section of politicians and the military.

The military-led praetorian oligarchy dominated politics and the state.

Bhutto-led politicians ran the affairs in an oligarchic alliance with civil bureaucracy and the military

The military-led praetorian oligarchy has ruled the roost.

Source: Data gathered from the existing accounts on Pakistan's civilmilitary relations.

The military, being part of the praetorian oligarchy, planned and fought a war against India over Kashmir in 1947-48. This exercise helped the oligarchy to rule authoritatively in the 1950s. The civil bureaucracy led the praetorian oligarchy in this period.

However from 1958 onward, the military has, from within the praetorian oligarchy, emerged as a powerful political actor due to 
142 its coercive power. It has become leader of the oligarchy. Though in the 1970s it disengaged from politics due to its defeat in the 1971 war and the country's disintegration, yet it regained its prestigious position in 1977. It ruled belligerently in the1980s. However, it again disengaged from politics in the 1990s due to a changed geostrategic environment. But the real power remained with the men in uniform in terms of 58 (B) 2 during this period.

The bureaucrat-feudal presidents, a part of the praetorian oligarchy, dismissed the so-called democratic governments formed by the landed-feudal class. In other words, the praetorian oligarchy politically remained dominant. In October 1999 - and also, in November 2007 - the military overtly intervened to exile an authoritative civilian who attempted to curtail military's politicoeconomic activities. Since then, the military-led praetorian oligarchy ruled the country. The clergy was auxiliary to this praetorian oligarchic rule.

As the study explained, all the coups were primarily economic in nature. The military sought political power to act as an independent economic actor. It allocated land among its personnel to expand the institution socially and economically. The other components of the praetorian oligarchy would ally with the military to pursue their politico-economic interests. Thus, the political power has laid with the Punjab-based praetorian oligarchy from 1947 partition until present. This power was exercised on none other but the urbanrural poor. In the absence of any (lower) middle-class leadership and political organisation, they have suffered and died in despair. Their state of affairs could be gauged from the State Bank of Pakistan's Inflation Monitor of August 2008. It stated:

Inflationary pressures strengthened in the economy with CPI inflation (YoY) soaring to reach 25.3 percent during August 2008 compared to 6.5 percent in the same month last year. Both food and non-food groups of CPI contributed in this upsurge in headline inflation. Food inflation (YoY) remained persistently high and was recorded at 34.1 percent compared to 8.6 percent in August 2007. This rising trend was mainly led by increase in the prices of some key food commodities 
such as coriander seed powder (130 percent), pulse masoor (130 percent), rice irri (121 percent), wheat (76 percent), and maida (68 percent). Similarly, non-food inflation (YoY) also increased significantly reaching 18.7 percent in August 2008 compared to 4.9 percent during the same month last year. Amongst the various components of CPI non-food group, transport and communication, house rent index (HRI), and fuel and lighting sub-group witnessed significant increase in inflation (YoY) during August 2008 compared to the same month last year. Other measures of inflation i.e. wholesale price index (WPI) and sensitive price indicator (SPI) also showed strong growth during the month under review. (Stat Bank of Pakistan 2010)

Finally, it has been argued that the theoretical framework in terms of the praetorian oligarchy was useful to civil-military relations in Pakistan. In addition, this article has developed theoretical concepts such as the Punjab-based praetorian oligarchy, overdeveloped civilmilitary bureaucracy, politics of appeasement, and military as prepartition phenomenon. They may be useful for future researchers. 


\section{Bibliography}

\section{Primary Sources}

CENSUS OF PAKISTAN (1951) Report and Tables. Karachi: CENSUS OF PAKISTAN.

Government of Pakistan (2005) Medium Term Development Framework 2005-10. Planning Commission: Government of Paskistan.

PILDAT (2003) Directory of the Members of the 12th National Assembly of Pakistan. Lahore: PILDAT.

State Bank of Pakistan, Government of Pakistan. 2008. Inflation Monitor. [cited 1 October 2010]. Available from http://www.sbp.org.pk/publications/Inflation_Monitor/2008/aug/ IM Aug_2008.pdf

\section{Secondary Sources}

\section{Books}

Ali, Tariq (1970) Pakistan: Military Rule or People's Power. London: Jonathan Cape.

Ali, Tariq (2002) The Clash of Fundamentalism: Crusades, Jihads and Modernity. London: Verso.

Alavi, Hamza (1988) 'Pakistan and Islam: Ethnicity and Ideology' in Fred Halliday and Hamza Alavi (ed.) State and Ideology in The Middle East and Pakistan. London: Macmillan Education Ltd.

Alavi, Hamza (1990) 'Authoritarianism and Legitimation of State

Power in Pakistan', in Subrata Kumar Mitra (ed.) The PostColonial State in Asia: Dialectics of Politics and Culture. New York: Harvester Wheatsheaf.

Burki, Shahid Javed (1980) Pakistan under Bhutto, 1971-77. London: Macmillan Press.

Burki, Shahid Javed and Craig Buxter (1991) Pakistan under the Military: Eleven Years of Zia ul-Haq. Colorado: Westview Press. Chadda, Maya (2000) Building Democracy in South Asia: India, Nepal, and Pakistan. London: Lynne Rienner Publishers.

Cohen, Stephen P. (1984) The Pakistan Army. Berkeley: University of California Press. 
Cohen, Stephen P. (2004) The Idea of Pakistan. New York: The 145 Brookings Institution.

Cheema, Pervaiz Iqbal (2002) The Armed Forces of Pakistan. Karachi: Oxford University Press.

Huntington, Samuel P. (1968) Political Order in Changing Societies. New Haven, CT: Yale University Press.

Husain, Haqqani (2005) Pakistan: Between Mosque and Military. Washington, DC: Carnegie Endowment for International Peace.

Hashami, Javed (2005) Han! Mein Baghi Hoon [Urdu: Yes! I am a Rebel].Lahore: Sagar Publications.

Jalal, Ayesha (1991) The State of Martial Rule: The Origins of Pakistan's Political Economy of Defence. Lahore: Vanguard Books Ltd.

Jalal, Ayesha (1995) Democracy and Authoritarianism in South Asia: A Comparative and Historical Perspective. Cambridge: Cambridge University Press.

Khan, Fazle Muqeem (1960) The Pakistan Army. Lahore: Sangle-eMeel Publications.

Perlmutter, Amos (1974) Egypt: The Praetorian State. New Jersey: Transaction Books.

Perlmutter, Amos (1981) Modern Authoritarianism. New Haven: Yale University Press.

Rizvi, Hasan Askari (2000) The Military and Politics in Pakistan: 1947-1997.Lahore: Sange-e-Meel Publications.

Rahman, Tariq (1998) Language and Politics in Pakistan. Karachi: Oxford University Press.

Steans, Jill and Lloyd Pettiford (2005) Introduction to Relations International: Perspectives and Themes. Essex: Pearson Education Limited.

Sayeed, K.B. (1967) The Political System of Pakistan. Boston: Houghton Mifflin Company.

Sayeed, K.B. (1980) Politics in Pakistan: The Nature and Direction of Change. New York: Praeger Publishers.

Sayeed, Shafqat (1997) Civil-Military Relations in Pakistan: From Zulfiqar Ali Bhutto to Benazir Bhutto. Colorado: Westview Press. Sarila, Narendra Singh (2005) The Shadow of the Great Game: The 

Untold Storey of India's Partition. New Delhi: HarperCollins Publishers.

Siddiqa, Ayesha (2003) 'Power, Perks, Prestige and Privileges: The Military's Economic Activities in Pakistan', in Jorn Brommelhorster and Wolf-Christian Paes (ed.) The Military as an Economic Actor: Soldiers in Business, pp. 124-142. Basingstoke: Palgrave Macmillan.

Siddiqa, Ayesha (2007) Military Inc: Inside Pakistan's Military Economy. Karachi: Oxford University Press.

Waseem, Mohammad (1994) Politics and the State in Pakistan. Islamabad: National Institute of Historical and Cultural Research.

Yong, Tan Tai (2005) The Garrison State: The Military, Government and Society in Colonial Punjab, 1849-1947. Lahore: Vanguard Book Ltd.

Ziring, Lawrence (1971) The Ayub Khan Era: Politics in Pakistan, 1958-69.Syracuse, N.Y.: Syracuse University Press. 